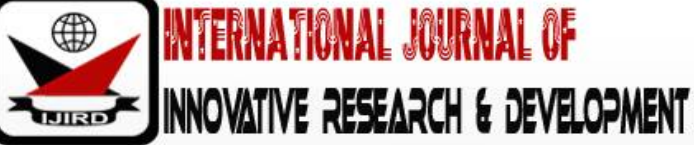

ISSN 2278 - 0211 (Online)

\section{How Independent Is the Independent Corrupt Practices and Other Related Offences Commission (ICPC) in Nigeria: Re - Visiting the Question of Autonomy in the Fight against Public Sector Corruption}

Dr. Hassan Achimugu
Lecturer, Department ofPublic Administration,
Kogi State University, Anyigba, Nigeria
Ogwu Ambrose Amanabo
Administrative Officer, Department of Procurement,
National Bio-Technology Development Agency, Abuja, Nigeria
Adaji Abdul
Field Officer, Department of Local Government Education Authority
Kogi State Local Government Service Commission, Lokoja, Nigeria

\begin{abstract}
:
The negative and mostly devastating consequences of corruption is perhaps the most compelling reason for which development - conscious nations of the world are resolved not to treat it with Kid - Gloves. It is an inordinate catastrophe that destroys socio-economic prosperity and the political development of any nation. This global predicament has had more than a fair share of the fabric and collective wealth of our lavishly endowed nation - Nigeria. Of more specific concern is the fact that corruption continues to thrive in spite of a constellation of legal/ institutional frameworks like the Independent Corrupt Practices and other Related Offenses Commission (ICPC), targeted at overcoming the menace. This paper adopts a Desk/ Documentary analysis, to ascertain the roles institutional autonomy plays in the fight against corruption, and to answer the question of the extent to which ICPC enjoys the level of autonomy needed to wage a successful war against corruption in Nigeria. The findings show, that the ICPC by its composition and formation lacks a specific mandate to exercise institutional surveillance, and prosecute suspects independently without government intervention. Besides, the agency is not independently funded. Its financial ties to the Apron Strings of the Federal Government seems to have reduced it to a dog that can bark, but can't bite friends and loyalists of the government of the day, but seeks credibility in serving as a tool for harassing and intimidating perceived enemies of the government. The paper recommends among others, a review of the ICPC Act 2000, to make the ICPC significantly independent of all the organs of government, along the lines of International Best Practices of setting up such anti - corruption institutions.
\end{abstract}

Keywords: Corruption, autonomy, institutions, political economy, development

\section{Introduction}

Corruption remains one of the trickiest menaces that most countries in the developing world are confronted with, and most times in its crudest and cruel forms. Its existence gives rise to sporadic advantages as opposed to legitimate and moral standards and dissolves the ability to secure the welfare of a nation (Osoba, 2006; Aluko, 2007 cited in Mikail and Abdullah, 2017). Corruption has really affected all nations across the globe especially the developing states in Africa, Nigeria included. It has affected both the developed nations and underdeveloped states (Eugene, 201, cited in Mikail and Abdullah, 2017). According to Nuhu (2013), corruption is a vicious cycle. Mismanagement of public funds has direct bearing on the Country's collapsing infrastructure, standard of education, health facilities, insecurity, injustice, unemployment, poverty and other challenges which are interconnected. The efficiency of public services and ability of the regulatory agencies to regulate the private sector are also affected resulting in the integrity of leaders and credibility of governments, it ends up with a total disrespect for authority. Inspite of the known negative consequences of corruption, it still persists in different areas and dimensions in Nigerian government. The negative and damaging aspect of corruption have been associated with greed and nepotism which are as a result of economic uncertainty and poverty, lack of sustainable social and income security and distorted social values. Abah (2005) covers that the virus of corruption has done a lot of harm to the democratic experiment in Nigeria as public officers more often than not regard their offices as goldmines and God sent opportunities to flagrantly loot and amass wealth. He sees corruption as an instrument of internal 
colonization and underdevelopment. He asserts that the claim to democratization in Nigeria would be a mirage if the legacies of corruption are not permanently cleaned up in a furious hurry. He notes that ex-public officials known to have ruined our treasury for years are being re-elected adding that people who took public funds are being rewarded with national honours and chieftaincy titles. In his reckoning, corruption is classified into three categories, namely; petty class, middle class and high-level class In the same vein, Chuta (2004) averred that developmental plans and policies are not executed or implemented according to specifications, corrupt tendencies are exhibited with absolute impunity, all these culminates in the decay and the underdevelopment of the country.

It is clear to every citizen of Nigeria that the level of corruption in the country is high and it is found in all the entire sectors of the country. In spite of the huge amount of yearly budget in the country, there is nothing to write home about in terms of national development. The endemic nature and debilitating effect of corruption on the cultural, economic, social and political foundation of the society has been most harrowing and disconcerting. Our economy has been dashed and our conscience, so sealed that we see corruption as a normal thing or way of life (Ngbede, 2015). Although, lack of political will by the government, political interference, lack of autonomy, paucity of funds among others are obstacles to the activities of ICPC, this study assesses the autonomy of the anti-corruption commission as it affects the accomplishment of its mandate.

\section{Conceptual Framew ork}

\subsection{Corruption}

Dike (2005) posited that the existence of corruption is not new to the world; in fact the history of corruption is as old as the world. Widespread illegality and corruption were traced to ancient civilizations. Old civilizations like ancient Egypt, Israel, Rome and Greece had records of corruption. Thus corruption existed in the past likewise in the modern day governments. According to Munyae and Lesetedi (2002:52), corruption is a universal phenomenon and a societal evil that plagues the whole system making it to function abnormally. Corruption is relative and it has no single definition since it means different thing to different people or society. It varies from one place to another. Caiden (2007:78) also posited that there is not an "all-purpose definition of corruption". But despite this, definition of corruption has been categorized into three different groups according to Werner (2001); Public office-centered definitions which is the deviation from legal and public duty norms to benefit oneself in any form; Market-centered definitions which view corruption as a maximizing unit where officials maximize pecuniary gains according to the supply and demand in the market-place of their official domain; Public interest-centered definitions, which focuses on the betrayal of public interests by preference of particular/ common interest. (Werner 2001:193.)

Otite (2000) hinted that "corruption is the pervasion of integrity or state of affairs through bribery, favour or moral depravity". He further pointed out that "corruption takes place when at least two parties have interacted to change the structure or processes of society or the behaviour of functionaries in order to produce dishonest, unfaithful or defiled situations". This description by the African anthropologist is the common attitudes of most African elites and Nigerian power brokers. Indeed, they used to connive towards changing the reality to favour their self-centric mission to the anguish of societal and national development. Corruption has affected all facets of human endeavours and is threatening the existence of developing countries by weakening control institutions, undermining the rule of law and good governance and destroying the economy. The most serious matter concerns the effects of debasement on state security, democratic governance and national development (Shehu, 2015).

From a narrower perspective, Onaiyekan (2008) sees public corruption as largely referring to the misuse of public funds or the appropriation of resources meant for the community into the private pocket. While Osoba (2005) defines it "as an anti-social behaviour conferring improper benefits contrary to legal and moral norms and which undermines the authorities capacity to secure the welfare of the state."

Corruption has created a legitimacy crisis between leaders and their followers and had caused a number of citizens to establish their own religious militancy, tribal or regional warlordism in order to challenge the state power through the withdrawal of their limited legitimacy from the state. A classical illustration is the militants' activities of the Niger Delta region and the menace of religious warlords of "Boko Haram" in the North eastern region of the country. In fact, such episodes emerge due to the absence of equity, justice and transparency in governance (Mikail and Abdullah, 2017).

\subsection{ICPC Mandate}

The ICPC was established in September 2000 via the ICPC Act 2000 to spear the declared war against corruption. This Act in Section 6 (a-f) conferred on the Commission the duties or mandates are to:

- Where reasonable grounds exist for suspecting that any person has conspired to commit or has attempted to commit or has committed an offence under this Act or any other law prohibiting Corruption, to receive and investigate any report of the conspiracy to commit, attempt to commit or the Commission of such offence and, in appropriate cases, to prosecute the offenders;

- Examine the practices, system and procedures of public bodies and where, in the opinion of the Commission, such practices, systems or procedures aid or facilitate fraud or corruption, to direct and supervise a review of the,

- Instruct, advise and assist any officer, agency or parastatal on ways by which fraud or corruption may be eliminated or minimized by such officer, agency or parastatal; 
- Advise heads of the public bodies of any changes in practices, systems or procedures compatible with the effective discharge of the duties of the public bodies as the commission thinks fit to reduce the likelihood or incidence of bribery, corruption and related offences;

- Educate the public on and against bribery, Corruption and related offences; and

- Enlist and foster public support in combating Corruption.

\subsection{Anatomy of Corruption}

The most common type of corruption is bribery, which refers to the given or taking of money or any kind of favour in return or exchange for undue advantage over other people. Other types include: Abuse of power in any form or degree, extortion, embezzlement, inflation of contracts, kickbacks, diversion of funds, falsification or suppression of record, pervasion of justice, electoral malpractice, examination malpractice, drug trafficking, money laundering, abuse of selection processes, nepotism, sexual exploitation, gratification etc. the list is not exhaustive as there are many other forms which are peculiar to organizations and circumstances. Some studies have taken a holistic approach in the discussion of corruption, into many forms and sub-divisions. Some of the various forms of corruption are stated and explained below:-

- Political corruption (Grand): The Encyclopedia Americana (1999), explains that political corruption takes place at the highest level of authority. The politicians and the political decision-makers, who are entitled to formulate, establish laws in the name of people, are themselves corrupt. It also takes place when people and legislation is tailored to benefit politicians and legislators. Political corruption is seen as similar to corruption of greed as it affects the manner in which decisions are being manipulated in the political institutions, rules of procedures distorts the established institution, which eventually affects the progress of the nation building.

- Bureaucratic corruption: The bureaucratic corruption occurs in the public administration or the implementation of public affairs. This form of corruption has been termed low level and street level. It is a kind of corruption that the citizens encounter every day, at different places like the hospitals, school, local licensing offices, government offices, and so many other areas. Bureaucratic petty corruption, is seen as similar to the ones mentioned above, occurs when one obtains a business from the public sector through inappropriate way.

- Favouritism: Favouritism is a mechanism of power abuse implying a highly biased form of giving out resources. Nevertheless, this is seen as a natural human tendency to favour friends, fans, choice and trusted ones. Nepotism: This is special form of favouritism in which an office holder prefers favouring his close ones and family members. This is also common in Nigeria.

- Embezzlement: It denotes "stealing money or other property that belongs to the government or the establishment where one works or does business. It comprises looting of pubic fun, cheating, misappropriation and even underperformance". Embezzlement is outright theft of entrusted funds. It is a misappropriation of property.

- Bribery: Bribery is an act of given money or gift personally to a government official with the aim of him using his official powers to influence or render favour to the party providing the bribe. It involves two participants, one to give the bribe, and another to receive the bribe. For example custom officials may demand bribes to let through allowed or disallowed goods or a smuggler might offer bribes to gain passage with illegal goods (Charlie, 2010).

- Kickback: A Kickback is a form of negotiated bribery in which a commission is paid to the bribe-taker as a quid pro quo for service rendered. However, the negotiation is usually done ahead of time. More so, a kickback is an official's share of misappropriate funds allocated form his or her organization to an organization involved in corrupt bidding. For example suppose a politician is in charge of choosing how to spend some public funds, he can give the contract to a company that will favor him, the official receives a kickback payment, which is a portion of the sum the company received. The sum may be all or a portion of the difference of the actual (inflated) payment to the company. Kickbacks are not limited to government officials; any situations in which people are entrusted to spend funds that do not belong to them are susceptive to this kind of corruption (Nick, 2007).

- Internets scan/advanced fee fraud: with the advent of internet communication technology, a new form of corruption emerges. It includes the use of internet messages to defraud people of their money or property. Messages promising financial benefits are sent to one's phone or e-mail as traps to defraud the receive millions of people are being defrauded through scam messages which they receive and are convinced by their contents.

- Extortion:- This is a criminal offense which occur when a group of people or a person unlawfully obtain money or property from another through intimidation or threat, violence or fear one with physical harm under the color of official right. (Legal-dictionary, the free dictionary. Com).

- Moral corruption: this type of corruption has been a pure collapse of moral values of our religion institutions. There has been the rising epidemic of religious to satisfy their materialistic quest. Most Nigerians now see religious institutions as a breed ground to enrich themselves. There has been complete mor al decadence on the part of those who are looking upon to promote moral values in the society. Religious leaders who should exude frantic effort to cleanse and rehabilitate the damage caused by corruption in the Nigerian society, are themselves wholly drenched in the scourge via their collision with the corrupt political and economic elite as well as the demonic individuals in the society.

- Procedural Corruption: This is the intentional use of legal -rational authority based on formal rules for personal gain instead of organizational goals. 
- Mismanagement: Mismanagement is a failure of competence in the handling of one or more tasks of planning, organizing and controlling an enterprise. Often, management is perceive as signified by the terms "failure" with little or no planning, organizing or controlling.

\subsection{Theories of Corruption}

\subsubsection{Social Control Theory}

Social control theory posits that without effective control measures; deviance becomes the norm; (Weidman, 2007 cited in Peter, Sunday and Bassey 2012). According to this theory, humans rationalize on what is more rewarding and proceed to take action on that basis. Thus, in the absence of fear of penalty or sanctions, there is nothing to deter people from fraudulently enriching themselves at the expense of others. As this phenomenon snowballs, it actually becomes accepted as a norm: as is currently the case with some forms of corruption in many African countries including Nigeria (Peter, Sunday and Bassey 2012).

\subsubsection{Socio-Cultural Theory of Corruption}

This view as stated by Medard (1998) cited in Peter, Sunday and Bassey (2012)holds that corruption is as a result of imposition of western methods of governance and upholding that system as opposed to our traditional system. Corruption in developing countries is often associated with inharmonious relationship between traditional values and western norms, which are evidenced in modernistic unbridled acquisition tendencies. In the first place, the origin and nature of the public service as a colonial instrument and the inherent contradictions between this and current nationalistic goals have continued to impede its efficiency, as governmental machinery in the postcolonial era. In its origin, the public service was based on colonial hostility to indigenous development interests. It can thus be concluded that corruption is an imported phenomena which came with colonization.

\subsection{ICPC and the Issue of Autonomy in the Fight against Corruption in Nigeria}

Njoku (2007) espouses the views of Marx (1867) who argues that the human person is bound to the structures and superstructures of society. That, his reasoning is determined by the consciousness which these structures bequeath to him and his actions are tied to socio-economic and political conditions and insist that the human person is a determination of social structures and forces. Consequently, change of the structures and superstructure of society and indeed the public service can lead to the behavioural change of public servants. In the fight against corruption in the Federal Public Service, the ADB (2006) observes the imperatives of anti-corruption institutions. The bank stresses that, though such institutions Code of Conduct Bureau (CCB), Independent Corrupt Practices and Other Related Offences Commission (ICPC), Economic Financial Crime Commission (EFCC) etc now exists, their ability to function effectively and the resources at their disposal vary. To be effective, the ADB (2006) adds that, the institutions must be autonomous.

Seth (2008:2) sees institutional autonomy as; ...the process and state by which an institutional core is constituted by a distinct set of material and symbolic resources, has a discrete set of organizational and individual actors with distinct activities, and finally, has a set of rules specifically addressing these actors and resources

This implies that institutions become differentiated from each other to the point where the actors of one institution are readily distinguishable from the actors of another, the symbolic resources are distinct, and while the material resources may overlap, their use and allocation will be institutionally specific. It is along these dimensions that one can determine the degree of autonomy an institution possess.

It is worthy to note that, autonomy neither implies self-sufficiency nor detachment, but is best understood with some type of qualifying adjectives like limited or relative autonomy.

From the foregoing, it is clear that, for ICPC to be effective in fighting corruption in the discharge of its mandate, it needed to be autonomous. However, institutional autonomy is not absolute but relative. Therefore, the anti-corruption institutions must be constituted by a distinct material and symbolic resources, discrete actors, and a particular set of rules delineating their relationships all in relative terms.

The lack of an authoritative lead organization, with a specific mandate, to exercise institutional surveillance and prosecute the suspect independently, without the government intervention is a major challenge of the ICPC in Nigeria. Apart from the fact that ICPC was not funded independently, it has not been empowered to carry out its responsibility independently as Federal government does intervene in its operation. Moreover, it is pertinent to note that a key instrument for preventing corruption is to have an independent anti-corruption commission, sufficiently funded and adequately empowered to investigate and prosecute misconduct of public officials in the handling of public resources without the undue influence of the Federal government. The lackadaisical attitude of the judiciary in Nigeria towards the cases of ICPC is a challenge to the autonomy of the commission. Meaningful progress will be made if the government can take the bull by the horn and fight the rot in judiciary by embarking on total reforms in the judicial sector.The federal government should be pragmatic enough in emulating countries like Ghana, Kenya, Britain and other advanced countries which had gone through similar experiences .It was revealed that cases of corrupt practices that happen to go to court of law in Kenya spend maximum of 90 days as stipulated by law (Musa, 2006). This will prevent the deliberate adjournments that are usually associated with such cases in a corrupt environment like ours. In his reaction to this challenge, the chairman of ICPC, Hon. Justice Emmanuel Ayoola had issued a warning to members of (the bench to desist from deliberate asking for adjournment of cases just to buy time (New Nigerian, 2005). The question is what happened to the cases of corrupt practices alleged to have committed by former speaker of House of Representative Olubunmi Etteh, then former minister of health Adenike George and many others that have been tactically buried.There is indication that all these cases 
and others have got swept under the carpet, all on account of inefficiency of the judiciary. Then how can we restore value into the society in which the judiciary is moribund and ineffective? The above position was also corroborated by the paper presented by the formal chairman of EFCC Nuhu Ribadu in 2004 titled Obstacle to Effective Prosecution of Corrupt Practices and Financial Crimes in Nigeria where he argued tenaciously that judiciary must wake up from its slumber for Nigeria to achieve a corrupt free society (Newswatch, 2004).

\section{Methodology}

Qualitative case study research design was used for this study. Qualitative case study method of research is one in many methods of doing research in social science. Case study is study which examines in some depth persons, decisions, programs, or other entities that are of unique characteristics of interest. This method is the most preferred research strategy by administrators when there is the question of how and why something happened. Thus examining ICPC as a case study research is an example of case study research. (O'Sullivan and Rassel 1989: 32-33).

\subsection{Major Finding}

A significant finding of this study is that the institution, by its act of omission and commission, appear to lack complete independence. The ICPC is very slow to act and cannot, strictu sensu, prosecute. The close affinities ICPC have with the presidency that created it in the first place, have made the commission to appear like instruments of state coercion and victimization of perceived and real enemies of the civilian administration. The above scenario is made credible by the selective investigations and prosecutions by the commission, particularly in handling cases of corruption involving politicians and those in the private sector who condemn Federal government policies. ICPC have been tinted that it has prima facie evidence of wrong-doing against a majority of state governors, but has not been able to prosecute them because of restraining legal frameworks. According to the 1999 Federal Constitution, immunity is conferred on 74 public office holders, including the President, Vice-President, 36 state governors, and 36 deputy governors, who can neither have criminal proceedings instituted against them or be arrested or imprisoned while in office. These provisions have been blamed for hindering anti-corruption because it is mainly top public office holders that commit heinous economic and financial crimes who yet hide under immunity throughout their tenure spanning four years or eight years if they get a second term.

Hence, ICPC in Nigeria is not independent; it is fully under the control of the government. ICPC does not have full autonomy to operate which is a pointer to the issue of lack of political will by the government to truly fight corruption to a standstill.

\section{Conclusion}

It is instructive to conclude that, there is high level of corruption in the public service which is rationalize by flimsy excuse like poverty, hunger, greed as well as selfish interest, bad leadership, tribalism, economic system of the country, influence of money, laziness and thinking of old age among others. The efforts of the government toward the fight against corruption in Nigeria notwithstanding, ICPC in Nigeria is just a toothless bull dog in her own right due to political influences on the commission. A project that was well established with the full backing of the law later became powerless due to pressures from the ruling government. Moreover, with the arrays of problems faced by ICPC, it makes the control of corruption an upheaval task in a country that is full of corruption like Nigeria. The anti-corruption institution has no full autonomy as it is one thing to establish anti-corruption institution, and another to give it full autonomy as a proactive measure for optimum performance.

\section{Recommendations}

In view of the findings, the following recommendations are made.

One, the enabling Act of the Commission should be reviewed by the National Assembly for effective performance in fighting corruption in Nigeria. The Act 2000 that set up the agency does not give the ICPC powers to investigate corruption cases before its birth. If the Act 2000 was reviewed, the ICPC would be pro-active. Secondly, there is duplication of agencies and the crisis of jurisdiction has affected their activities. Hence, ICPC would have done better if not for the challenges militating against its operation. For the agency to live up to expectations, all the clogs in the wheels of the commission should be removed. Thirdly, anti- corruption agency in Nigeria should follow the international procedure for creating an anti-corruption body. ICPC in Nigeria is not independent; it is fully under the control of the government. For a true fight against corruption in Nigeria, any anti-corruption establishment must be independent of all the three arms of government in Nigeria. And also ICPC must be financially independent. Getting budget from the government hampers the performance of ICPC in the fight against corruption. It is therefore important for ICPC to have full autonomy. The national assembly should urgently enact a law to make the anti- corruption agencies totally autonomous.

\section{References}

i. Abah, O. (2005): Destined for the Trash, Tell Magazine. Vol. 4, No. 24, P 64, March 7, 2005.

ii. Charlie, F (2010). Cash Bribe put Patients a top Surgery waiting list. The Vanconver Sun.

iii. Chuta, S.E. (2004): Corruption in Nigeria. Nsukka: Afro-orbis Publications Limited.

iv. Dike, V. (2005). Corruption in Nigeria: A New Paradigm for Effective Control Art Sacramento UniversityPress available at www.amazon.com. 
v. Encyclopedia Amaricana (1999). Danbury. Conn: Grolier Inc. www.worldcat.orgl ICPC (2004), "Nigeria Independent Corrupt Practices and other Related Offences Commission: a Brief Overview". Available on-line at URL http:/ / www.Icac.org.hk/ news/ issue1 7eng/ button2.htm

vi. Mikail1, I.K and Abdullah, M. A. L. I (2017) Challenges in Combating Corruption in Nigerian Democratic Dispensation and its Possible Solutions. Journal of Techno Social, ISSN 2229-8940, pp 53-61

vii. Ngbede, I.O. (2015): Corruption Bane of Nigeria Development: The Observer, 23rd June, 2015.

viii. Nick, M (2007). Western Bankers and Lawyers rob Africa of \$150bn every year. London observer. Guardian.co.uk

ix. Njoku, U.J. (2007). Corruption and Social Change in Federal Public Service and the Agency - Structure Debate.

x. Nuhu, R. (2004). Corruption costs Nigeria 40 percent of oil wealth "Retrieved from http:/ / www.boston.com/news/ world/ africa/ articles/2011/07/17/ corruption_costs_nigeria_40 percent of oil wealth official says?

xi. Nuhu, R. (2013), Corruption and National Development. Daily Post, January 27

xii. Onaiyekan, J. (2008). Anti-Corruption and Value Orientation. Delivered at a Retreat for Ministers and Permanent Secretaries, Abuja.

xiii. O'Sullivan,E and Rassel, R.G ( 1989), Research Methods for Public Administrators. The University of Michigan, Longman.

xiv. Osoba. S. (2005). Corruption in Nigeria. In the Washington Post Company Retrieved on December 2, 2008 from www.washingtonpost.com

xv. Otite, O. (2000). "Corruption against the Norms of African Life in Femi, O. (ed.) Effective and Efficient Implementation of Nigeria's Recent Anti-Corruption Legislation.

xvi. Peter S. U, Sunday A. E and Bassey E. (2012). Corruption and its implications for actualizing Nigeria vision 202020. Global journal of social sciences vol.11,(1),41-51 www.globaljournalseries.com; email: info@globaljournalseries.com

xvii. Seth, A. (2008). A General Theory of Institutional Autonomy. Retrieved on 11/23/2008 from http://www. allacademic.com

xviii. Shehu, A.Y. (2015). "Nigeria the Way Through to Corruption to the well-being of a People". National Open University of Nigeria, Lagos. 